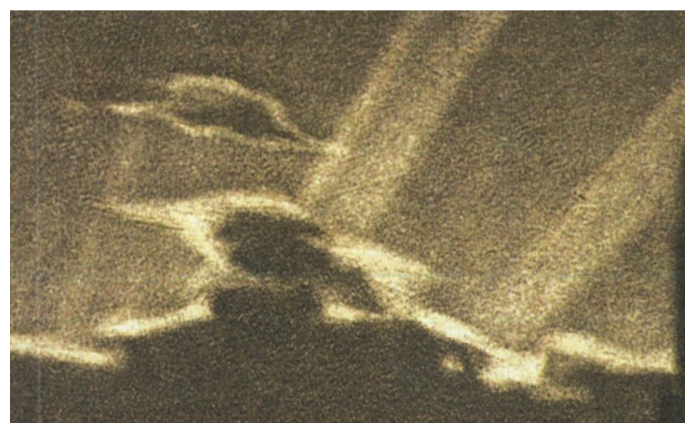

\title{
Australian
}

Books and

Authors in

the American

Marketplace

$1840 s-1940 s$

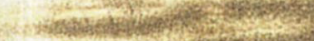

DAVID CARTER and ROGER OSBORNE

SYDNEY STUDIES IN AUSTRALIAN LITERATURE 


\section{Australian Books and \\ Authors in the American \\ Marketplace 1840s-1940s}

David Carter and Roger Osborne

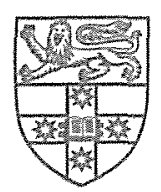

SYDNEY UNIVERSITY PRESS 
First published by Sydney University Press

David Carter and Roger Osborne 2018

- Sydney University Press 2018

\section{Reproduction and communication for other purposes}

Except as permitted under the Act, no part of this edition may be reproduced, stored in a retrieval system, or communicated in any form or by any means without prior written permission. All requests for reproduction or communication should be made to Sydney University Press at the address below:

Sydney University Press

Fisher Library $\mathrm{F} 03$

University of Sydney NSW 2006

AUSTRALIA

sup.info@sydney.edu.au

sydney,edu,au/sup

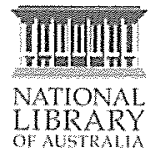

A catalogue record for this book is available from the National Library of Australia.

ISBN 9781743325797 paperback

ISBN 9781743325803 epub

ISBN 9781743325810 pdf

Cover image: Morning on the River, 1918, mezzotint by Martin Lewis (born 1881 in Castlemaine, Victoria; died 1962 in New York, New York). Reproduced by permission of the Old Print Shop, Inc., on behalf of the artist's estate. Cover design by Miguel Yamin. 


\section{Contents}

List of figures vii

List of plates $\quad$ ix

Acknowledgements $\quad$ xi

Introduction: The Two-Sided Triangle

1 Antipodean Romance: Australian Fiction and the American Book Trade in the 15 Nineteenth Century

2 International Reputations and Transatlantic Rights: Rosa Praed and Louis 51 Becke

3 Crime, Sensation and the Modern Genre System: Australian Authors in the 83 Popular Fiction Marketplace, 1890s-1920s

4 Renegotiating the American Connection: Australian Fiction 1900-1930s 111

5 Mystery and Romance: The Market for Light Fiction Between the Wars $\quad 161$

6 Becoming Articulate: Henry Handel Richardson and Katharine Susannah 195 Prichard

7 "Australia is very American": Australian Historical Fiction in America 231 $1920 \mathrm{~s}-1940 \mathrm{~s}$

8 "Australian moderns": Christina Stead and Patrick White in New York 271

9 Bestsellers, Modest Sellers and Commercial Failures: The Postwar Years 313

Epilogue: Completing the Triangle?

Works Cited $\quad 345$

Index $\quad 359$ 



\section{List of figures}

Figure 1.1 Charles Rowcroft, The Australian Crusoes; or, The Adventures of an English Settler and his Family in the Wilds of Australia (Philadelphia: Davis, Porter \& Co., 1865).

Figure 1.2 Tasma, A Sydney Sovereign and Other Tales, Aldine edition (New York: Frank F. Lovell \& Co., 1890).

Figure 1.3 Rolf Boldrewood, The Crooked Stick or Pollie's Probation (New York: Macmillan \& Co., 1895).

Figure 2.1 Advertisement for Rosa Praed, Nülma: An Anglo-Australian Romance (New York: D. Appleton \& Co., 1897). New York Times, 3 July 1897.

Figure 2.2 "Mrs. Praed. The Novelist Whose 'Mrs. Tregaskiss' Has Made a Stir." Louisiana Populist (Natchitoches, LA), 21 February 1896.

Figure 2.3 Louis Becke and Walter Jeffery, The Mutineer: A Romance of Pitcairn Island

(Philadelphia: J. B. Lippincott Co., 1898).

Figure 3.1 Fergus Hume, The Steel Crown (New York: G.W. Dillingham Co., 1911).

Figure 3.2 Guy Boothby, Dr. Nikola's Experiment (New York: D. Appleton \& Co., 1899)

Figure 3.3 Advertisement for Guy Boothby's The Race of Life (New York: F.M. Buckles \& Co,, 1906). New York Sun, 19 May 1906.

Figure 4.1 James Frances Dwyer, "The White Waterfall", announced for the Cavalier. Washington Times, 11 April 1912.

Figure 4.2 Ethel Turner, Seven Little Australians, Girls' Own Library (Philadelphia: David McKay, 1909 ?).

Figure 4.3 Advertisement for All for Love by Jean Devanny (New York: Macaulay Publishing Co., 1932). New York Times, 29 January 1933.

Figure 4.4 Advertisement for Norman Lindsay's Mr. Gresham and Olympus (New York: Farrar \& Rinehart, 1932). New York Times, 28 February 1932.

Figure 5.1 Advertisement for A.E. Martin's The Outsiders (New York: Simon \& Schuster, 1945). New York Times, 8 April 1945. 
Figure 5.2 Arthur Upfield in the Doubleday Crime Club. New York Times, 22 August 1948.

Figure 5.3 "America's best loved novelist". Advertisement for Alice Grant Rosman's The Sleeping Child (New York: Minton, Balch, 1935). New York Times, 23 June 1935.

Figure 6.1 Advertisement for Henry Handel Richardson's Ultima Thule (New York: W.W. Norton \& Co., 1929). New York Times, 8 September 1929.

Figure 6.2 Advertisement for Henry Handel Richardson's The Fortunes of Richard Mahony trilogy. Saturday Review of Literature, 12 April 1930.

Figure 6.3 Advertisement for Katharine Susannah Prichard's Coonardoo (New York: W.W. Norton \& Co., 1930). New York Times, 16 March 1930.

Figure 7.1 C. Hartley Grattan's review of Brian Penton's Landtakers (New York: Farrar \& Rinehart, 1935). New York Times, 16 June 1935.

Figure 7.2 Advertisement for Xavier Herbert's Capricornia (New York: Appleton-Century, 1943). New York Times, 9 May 1943.

Figure 7.3 Eleanor Dark's The Timeless Land (New York: Macmillan, 1941), Book-of-the-Month Club News, September 1941.

Figure 8.1 Advertisement for Christina Stead's Seven Poor Men of Sydney (New York: D. Appleton-Century Co., 1935). New York Times, 24 March 1935.

Figure 8.2 Advertisement for The Man Who Loved Children (New York: Simon \& Schuster, 1940). New York Times, 21 October 1940.

Figure 8.3 Advertisement for Patrick White's The Tree of Man (New York: The Viking Press, 1955). New York Times, 31 August 1955.

Figure 9.1 Advertisement for Jon Cleary's You Can't See Around Comers (New York: Charles Scribner's Sons, 1947). New York Times, 5 October 1947.

Figure 9.2 Advertisement for Kylie Tennant's The Battlers (New York: Macmillan, 1941). New York Times, 31 August 1941. 


\section{List of plates}

Plate 1 Tasma A Sydney Sovereign (New York: George Munro, 1890). 151

Plate 2 Rosa Praed, Fugitive Anne (New York: R.F. Fenno \& Co., 1904). 152

Plate 3 Louis Becke, By Reef and Palm and His Native Wife (Philadelphia: J.B. Lippincott Co., 1900).

Plate 4 The original japoniste cover of Carlton Dawe's Rose and Chrysanthemum (Boston:

Knight \& Millet, 1900).

Plate 5 Ambrose Pratt, The Living Mummy (New York: Frederick A. Stokes Co., 1910).

Illustration by Louis D. Fancher.

Plate 6 Dale Collins, Idolaters (Boston: Little, Brown \& Co., 1932).

Plate 7 Maysie Greig, "Kid Sisters Don't Count”, American Weekly, 17 September 1933.

Plate 8 First edition dust-jacket of Christina Stead's For Love Alone (New York: Harcourt, Brace, 1944).

Plate 9 Kylie Tennant, The Battlers (New York: Macmillan, 1941).

Plate 10 Tom Collins [Joseph Furphy], Such is Life (Chicago: University of Chicago Press, 1948). 



\section{Acknowledgements}

The research for this book was supported by an Australian Research Council Discovery Project grant (DP0771376: America Publishes Australia). Much of the research and writing was conducted within the School of English, Media Studies and Art History, then the School of Communication and Arts, at the University of Queensland, and with the support of Kerry Kilner and the staff of AustLit, located in the school, and the university's Fryer Library. Research was also conducted during David Carter's Harold White Fellowship at the National Library of Australia. Parts of the book were written in the Center for Pacific and American Studies at Tokyo University.

The authors would like to thank Susan Ballyn, Nicholas Birns, Barbara Brooks, Stephen Crofts, Maryanne Dever, Robert Dixon, Clay Djubal, Paul Eggert, Jason Ensor, Anna Gerber, Per Heningsgaard, Carol Hetherington, Lise Jaillant, Joan Keating, Marilyn Lake, Jenny Rundle, Lucy Sussex, Trysh Travis, Naomi Wakayama and Gillian Whitlock for their support and contributions to the book through discussions, research assistance or conference invitations. Sections of the research have been presented at conferences organised by the Association for the Study of Australian Literature (ASAL), the American Association of Australasian Literary Studies (AAALS), the Modern Languages Association (MLA), the Society for the History of Authorship, Reading and Publishing (SHARP), the Australian literature program of the Department of English at the University of Sydney, the Australian Centre, University of Melbourne, and the Australian Studies Centre (CEA), Universitat de Barcelona.

Extensive research was conducted in libraries and archives in Australia, the United States, and Britain. The authors would like to acknowledge the assistance of staff at the following institutions: Manuscripts, National Library of Australia; Mitchell Library, State Library of New South Wales; Baillieu Library, University of Melbourne; Fisher Library, University of Sydney; New York Public Library and the Berg Collection, New York Public Library; Library of Congress; Rare Books and Manuscript Library, Ohio State University; Lilly Library, University of Indiana; Rare Books and Manuscripts Library, Columbia University; Fales Library and Special Collections, New York University; Houghton Library, Harvard University; Harry Ransom Collection, University of Texas, Austin; Rare Books and Special Collections, Princeton University; University of North Carolina Library; Special Collections, University of Reading; London Metropolitan Archives; the British Library. 
As editor of the Sydney Studies in Australian Literature series, Robert Dixon gave strong support to the project and its publication, backed by Susan Murray, Manager, Scholarly Publishing, and the editorial expertise and enthusiasm of Agata Mrva-Montoya and Denise O'Dea at Sydney University Press.

Research projects such as this do not stop at the gates of our institutions, and so additional time and support is regularly provided by those closest to us. Roger would like to acknowledge the ongoing support and encouragement of Sonya Osborne, a gift that extends far beyond the boundaries of this project. David would like to acknowledge Rebecca Chorfadi for all her support and patience, before, during and also far beyond.

The image of the dust-jacket for Christina Stead's For Love Alone was kindly provided by Cathy Lilburne, Antipodean Books, Maps \& Pictures, Garrison, New York. The cover image from Morning on the River (1918) by Australian-born, New York-based artist Martin Lewis (1881-1962) is reproduced by kind permission of Robert K. Newman, The Old Print Shop, New York, on behalf of the Martin Lewis Estate. 


\section{Introduction: The Two-Sided Triangle}

The story of Australian books and authors in the American marketplace has received little attention in Australian literary or publishing studies. If considered at all, an Australian presence in the US book market is probably understood as a recent phenomenon, beginning perhaps with the success of Peter Carey, Elizabeth Jolley and others in the 1970s, or in a different register with Colleen McCullough's international bestseller The Thorn Birds (1977) or Thomas Keneally's Schindler's List (1982). This "memory" might itself be the effect of framing Australian literature in predominantly national terms, as developing progressively or dialectically through colonial, national and modern phases, so that a serious international presence could only exist in the latest stage. The present study reveals a much longer history stretching back to the mid-nineteenth century, with a significant concentration of Australian novels published in the United States in the 1880s and 1890s, another period of marked impact between the wars, and significant instances of success in popular fiction across the twentieth century. It is also a much denser, more diverse history in terms of the sheer number and kinds of books and authors published. One of the earliest scholars to indicate that this might be the case was Laurie Hergenhan, in his 1995 study of the influential American Australianist C. Hartley Grattan:

American editions of Australian works ... [are] more extensive than has been realised, for they have been typically overshadowed by interest in ... the English aspects of Australian publishing history. Few realise, for instance, that Patrick Whites first popular success was the American edition of The Tree of Man (the first edition of that novel), that Martin Boyd's Lucinda Brayford was a Book Society's choice and bestseller in America or that Eleanor Dark's The Timeless Land was also popular as a Book of the Month choice. ${ }^{1}$

Some of the gaps in knowledge have been filled in recent years by major biographies of individual authors such as G.B. Lancaster, Christina Stead and Patrick White, and by scholarly editions of selected canonical works. To varying degrees, these publications offer specific histories of their subjects' American editions and critical reception, and we have drawn on them accordingly.

1 Laurie Hergenhan, No Casual Traveller: Hartley Grattan and Australia-US Connections (St Lucia: University of Queensland Press, 1995), 47. 
Even so, the history of Australian books and authors in the United States remains very largely an untold story, not just in terms of numbers or the often surprising critical or sales success of individual titles and careers, but also in terms of the cultural and commercial dynamics and the personal, professional and institutional networks linking Australian authors with American publishers or putting obstacles in their way. To tell this story is not just to add a new layer to Australian literary history but to unsettle and reconfigure some of the foundational assumptions of that history. Once we add America into the picture things start to move, to shift beyond the framework of the national culture and the singular relationship between imperial centre and colonial outpost. Australia's place in the world republic of letters needs a new trigonometry.

What follows is a study of the relations between Australian authors, editors and publishers on one side and American publishers, editors, agents and reviewers on the other; or rather it is in part, for historically these relations were rarely simple or direct. The vast majority of Australian works that made their way to the United States did so via London, and hence via the intervention of British publishers, editors, agents and reviewers or the London-based representatives of American firms. The story thus, unavoidably, also involves the shifting relations each side had with the British book trade and how these relations in turn affected their understanding of each other as nation, industry or market. The history that needs telling is that of the triangulation of the Australian, British and American publishing industries and markets, a story of transnational structures and dynamics involving a complex mix of culture, copyright and commerce. It is to these relationships that our introduction's subtitle, "The Two-Sided Triangle", refers, for while there are clearly three nodes constituting this publishing triangle, for the most part only two "sides" were activated or rendered dynamic in the relationship: the imperial connection between Australia and London, and the transatlantic connection between the British and American book trades and book cultures. A number of recent studies have testified to the defining significance of the transatlantic book trade for the United States, but it was a major consideration for British publishers as well. ${ }^{2}$ By the mid-twentieth century it was estimated that a British edition of a book would sell domestically at best only 10 per cent of what it would in the United States. ${ }^{3}$ Publication in one market was often the start of a two- or three-step process that led to publication in the other, with the aim of increasing profits for publisher, author, or both. Our study shows that works of fiction by Australian authors should be recognised as a persistent, occasionally prominent element in this transatlantic trade.

2 See Jessica Despain, Nineteenth-Century Transatlantic Reprinting and the Embodied Book (Farnham, UK: Ashgate, 2014); Nancy Glazener, Literature in the Making: A History of US Literary Culture in the Long Nineteenth Century (New York: Oxford University Press, 2016); Meredith McGill, American Literature and the Culture of Reprinting 1834-1853 (Philadelphia: University of Pennsylvania Press, 2007); Michael Winship, "Anglo-American Literary Culture and the Transatlantic Book Trade in the Nineteenth Century", in Reciprocal Influences: Literary Production, Distribution, and Consumption in America, ed. Steven Fink and Susan Williams (Columbus: Ohio State University Press, 1999), 98-122. Also David Carter, "Transpacific or Transatlantic Traffic? Australian Books and American Publishers", in Reading Across the Pacific: Australia-United States Intellectual Histories, ed. Robert Dixon and Nicholas Birns (Sydney: Sydney University Press, 2010), 339-59.

3 Mary Nell Bryant, "English Language Publication and the British Traditional Market Agreement", Library Quarterly, 49 (October 1979): 374. 
Australian publishing history has, with good reason, focused on the British or imperial connection, often framed through the themes of the British book trade's dominance over Australian publishing and its domestic book market or local publishing's emergence out from under the British yoke. The dominance of the British book trade is undeniably fundamental to any account of Australian literary or book history, a fact confirmed by the present study. As Richard Nile and David Walker have put it, London was the "production centre for Australian literature" and the "commercial centre of the literary world"4 As a result, Australian publishing was a "tale of three cities", with Sydney and Melbourne subordinate to the great London publishing machine. But while this perspective expresses a central truth of Australian book history, it also renders invisible the other great commercial centre of the Anglophone literary world - New York (and Boston, Chicago, Philadelphia, the other main centres of American publishing). In so doing it ignores an important dimension of the histories of authors, books, and the book trade itself.

Recent studies of books and reading in colonial and early twentieth-century Australia have presented a complex picture of readers, writers and publishers engaging actively with both local and international, conventional and modernising print cultures. ${ }^{5}$ This complication of what occurred within domestic boundaries is matched by the complications produced by extending the outward horizon as well, not just beyond the nation but also beyond the imperial connection. The new imperial history has foregrounded the dynamic interconnections between the imperial centre and its colonies and dominions, and more specifically the presence of a "mobile imperial commons" of print across the empire. ${ }^{6}$ As such, the imperial connection can be understood not merely as a constraining factor but also a productive force, a critical vector of literary meaning and cultural modernity. If Australian novels were more or less compelled to travel first to London or to originate there to achieve book publication, London could also act as a relay station, giving books the power to travel further, and what we might call the power to be modern. But the emphasis on empire can also blind us to other networks and vectors of mobility. These might be complementary, as in the larger idea of an Anglo-Saxon world that embraced the United States; or they might need to be understood in quite other

4 Richard Nile and David Walker, "The 'Paternoster Row Machine' and the Australian Book Trade, 1890-1945", in A History of the Book in Australia 1891-1945: A National Culture in a Colonised Market, ed. Martyn Lyons and John Arnold (St Lucia: University of Queensland Press, 2001), 3 and 7; and "Marketing the Literary Imagination: Production of Australian Literature, 1915-1965", in The Penguin New Literary History of Australia, ed. Laurie Hergenhan (Ringwood, Vic.: Penguin, 1988), 286.

5 See, for example, Katherine Bode, Reading by Numbers: Recalibrating the Literary Field (London: Anthem Press, 2012); David Carter, Always Almost Modern: Australian Print Cultures and Modernity (North Melbourne, Vic.: Australian Scholarly Publishing, 2013); Ken Gelder and Rachael Weaver, The Colonial Journals and the Emergence of Australian Literary Culture (Crawley, WA: UWA Publishing, 2014); Susan Martin and Kylie Mirmohamadi, Sensational Melbourne: Reading, Sensation Fiction and 'Lady Audley's Secret' in the Victorian Metropolis (North Melbourne, Vic.: Australian Scholarly Publishing, 2011).

6 For an extended discussion of the concept of an imperial print commons that brings together perspectives from book history and the new imperial history, see Antoinette Burton and Isabel Hofmeyr, "The Spine of Empire? Books and the Making of an Imperial Commons", in Ten Books That Shaped the British Empire: Creating an Imperial Commons, ed. Antoinette Burton and Isabel Hofmeyr (Durham, NC: Duke University Press, 2014), 3-7. See also Robert Dixon, Photography, Early Cinema and Colonial Modernity: Frank Hurley's Synchronized Lecture Entertainments (London: Anthem Press, 2012), xxiv-xxix. 
terms, the terms of trade for example, as when we understand the mobility of books primarily in their capacity as saleable commodities rather than bearers of ideology. The transatlantic book trade, crucial to the present study, was a complex mixture of both across two relatively autonomous industry structures, conscious equally of their complementarity and their distinctiveness. In many ways, New York was itself subordinate to London as a publishing centre for much of the period under discussion. Imports of British books remained high even as local publishing expanded in the United States from the $1920 \mathrm{~s}$. But the New York book trade was also powerful enough in its own right to attract writers and writing from across the globe.

Our focus is primarily on book publication rather than serialisation in newspapers and magazines, although we emphasise the major role that periodical publication could play in building authors' reputations and earnings. Among these published books, our focus is primarily on the novel and related forms, as fiction is far and away the largest and most visible category of Australian works published in the United States. It is impossible to fix absolutely reliable numbers of American editions of Australian works due to the patchiness of bibliographical and archival records and the widely varied practices of authorised and unauthorised reprinting. But research indicates that around one thousand editions of novels with a significant Australian connection were published in book form in the United States to 1950 . This total comprises more than 760 different works, many in multiple editions, and almost certainly underestimates the number of reissues of individual titles. Almost 250 different authors appear from around 200 American publishing houses or major imprints. Doubleday in its various manifestations is by far the largest contributor, with more than one hundred titles between 1902 and 1950 and many more through its paperback subsidiaries; by the 1940s, it was America's largest publisher. Other mainstream American houses also published substantial numbers, including established firms such as Appleton, Scribner, Dodd, Mead, Dutton, Harper, Lippincott and Macmillan, hardback reprinters such as Grosset \& Dunlap, and newer enterprises such as The Dial Press and the Macaulay Company. From the 1920s, the most important emerging publishers such as Farrar \& Rinehart, Random House, Simon \& Schuster, William Morrow, the Viking Press and W.W. Norton also become involved.

The chapters that follow examine the pathways and processes that determined how Australian novels came to American publishers and how American publishers came to Australian novels. Such a study demands close attention to the "undergrowth" as well as the tallest trees, to the many lesser-known writers who achieved American publication and the extent and diversity of such publication is one of the findings of our research - as well as to the now canonical authors who succeeded or failed in the American marketplace. Taking its primary bearings from book history, on one level our approach means treating all books equally, as more or less tradeable and marketable commodities. Our focus is on fiction and books in the book trade, not on "literature", and from this perspective literary fiction and light fiction are merely different market sectors. At the same time, however, this very focus on the industry and the fiction marketplace demands heightened attention to the difference literature or literary value can make. For on another level, within the book trade itself, literary fiction and light fiction were not treated equally, even if as commodities they were subject to similar processes. Publishers, editors, agents and reviewers were acutely aware of the different kinds and levels of fiction, the different kinds of investment that might be risked (for example, in good books that were unlikely to return a profit), and the different kinds of reception books might receive. To borrow a notion from 
Ross Chambers, the "interpretability" of texts making claims to literary significance often produced a difference in both the quantity and quality of critical and editorial attention they received. ${ }^{7}$ Of course, the contemporary evaluations of publishers and reviewers would not always be those of later criticism, but judgements as to quality and kind were the everyday business of the book trade.

In tracing publishing histories, then, we have paid close attention to these processes of evaluation, to the circulation of different notions of genre and literary value, and hence to the kinds of attention - in the industry and the marketplace - that a major work such as Henry Handel Richardson's Fortunes of Richard Mahony trilogy could receive. In line with a number of recent studies of publishing and modernity in early to mid-twentieth-century America, what has emerged clearly from our own work with publishers' and agents' records and the book pages of newspapers and magazines is that these mainstream institutions ranged widely and, for the most part, without anxiety across the field of fiction, accommodating both modernism and modern genre fiction (within certain limits). ${ }^{8}$ Even as they register the twin forces of modernism and the popular fiction market, there is little evidence of the kind of dramatic polarisation of the field into antagonistic high/modernist and low/commercial categories that later criticism would project, although "excesses" and "fads" on either side were exposed and resisted. In publishers' lists and book review pages, crime and romance existed alongside realist family dramas, "modern novels", ambitious historical sagas, comic tales and the rest, not as the same kind of thing or as of equal value, but as belonging in the same field nevertheless. Literature and "good books" were valued, and Australian works could share in that prestige, but the ordinary business of books was broad in scope and generous in its sense of different kinds of books and readers.

Thus the books and authors we follow extend from the lightest of light fiction to the most literary of literary novels, from the most ephemeral of literary works to the most enduring of popular stories, as they variously reveal critical dimensions of our key questions: how Australian books and authors found their way into the American marketplace and how they flourished or floundered once they got there. Our focus is not simply on books as commodities, but on the relationships between the commodity, its creator and the various agents involved in its production as a book. The study thus works in two dimensions: on one side, tracing the careers or trajectories of individual writers and books in the American marketplace and American book culture; on the other, tracing the economic, legal and institutional forces shaping the American publishing industry and the transatlantic book trade, and shifts in taste and the language of literary appreciation that affected the publishing opportunities for Australian authors. We have not focused in as much detail on bookselling or distribution, except to describe the impact of the three major developments or disruptions in standard practice in the period covered: the rapid growth of cheap fiction libraries in the 1870s and 1880s; the launch of the

7 Ross Chambers, Story and Situation: Narrative Seduction and the Power of Fiction (Minneapolis: University of Minnesota Press, 1984), 12-13.

8 Gordon Hutner, What America Read: Taste, Class, and the Novel, 1920-1960 (Chapel Hill: University of North Carolina Press, 2009); Lise Jaillant, Modernism, Middlebrow and the Literary Canon: The Modern Library Series, 1917-1955 (London: Pickering \& Chatto, 2014); Karen Leick, "Popular Modernism: Little Magazines and the American Daily Press", PMLA 123 (January 2008): 125-39; Joan Shelley Rubin, The Moking of Middlebrow Culture (Chapel Hill: University of North Carolina Press, 1992); Catherine Turner, Marketing Modernism Between the Two Wars (Amherst: University of Massachusetts Press, 2003). 
Book-of-the-Month Club and other book clubs between the wars; and the rise of the new paperback publishers in the 1940s and 1950s.

A group of major figures - Rosa Praed and Louis Becke, Henry Handel Richardson and Katharine Susannah Prichard, Christina Stead and Patrick White - have been selected for extended case studies, while the American careers of other writers with marked impact in the United States such as Rolf Boldrewood, Fergus Hume, Arthur Upfield, Dale Collins and Alice Grant Rosman receive extended treatment in chapters covering specific periods or market sectors. These case studies are embedded in discussions of the changing copyright regimes for foreign books in the United States, the structures of the American (and British and Australian) book trade, its patterns of growth or decline, the role of literary agents, and significant cultural transitions such as the emergence of the modern genre system, the shifting meanings of romance, realism and modernity, and the rise and fall of the historical saga as a prominent form between the wars. Alongside such industrial and commercial factors as changes in the composition of US publishing and the "business" of investing in new titles, genre emerges as a key driver in determining which books travelled and just how they arrived in the American marketplace. Modernity, too, emerges as an important measure for both literary and popular fiction. It could be difficult for Australian writers to be comprehended within modernity in quite the same way as their British or American contemporaries, although for certain books at certain times it provided the key framework for their reception.

An informal understanding between British and American publishers - sometimes contested but largely respected - divided the Anglophone publishing world into two spheres. Britain guarded its "traditional markets" - "Great Britain, its Colonies and Dominions" as contracts declared - while the United States had uncontested access to the Americas and the Philippines. ${ }^{9}$ Canada was often disputed, and having access to the Canadian market could prove the difference between acceptance and rejection by a US publisher for a book on offer from London. With the global marketplace divided in this manner, and Australia locked firmly into the British sphere, there are relatively few instances of works travelling directly from Australia to the United States or of US publishers seeking new titles directly from publishers or authors in Australia, although we have noted examples of both. Angus \& Robertson, for example, actively sought American publication for some of its successful titles in the 1930s and 1940s, bypassing London through direct negotiations with US publishers and its own literary agent in New York. But its success was limited.

Despite these constraints, and of course in response to them, many Australian writers were highly conscious of the American market and the opportunities it could provide for further publication, reputation and profits. The very dominance of London publishing's "Paternoster Row machine" made America an attractive proposition for Australian writers whether based in Australia, travelling, or expatriated overseas. From Rolf Boldrewood and Ada Cambridge, through Rosa Praed and Ethel Turner, to Maysie Greig, Xavier Herbert and Patrick White, Australian writers were keenly interested (in the full sense of that word) in being published, publicised and reviewed in America and in maximising their earnings from the publications that did occur. Many took matters into their own hands, arguing with their British publisher about their efforts in the American market, signing with a London-based literary agent in order to get better deals in the United States, engaging

9 Bryant, "English Language Publication", 374-78. 
an American agent directly, establishing personal relations with American publishers, travelling to the United States or writing expressly for that market, and badgering publishers and agents in both countries about the opportunities and obstacles presented by international copyright law and subsidiary rights. The separation of the British and American markets even as the transatlantic book trade was expanding led to a growing awareness among authors of the value of their works as literary property and of the management of rights and royalties, which led, in turn, to the increasing role of the literary agent in dealing across national borders. This was especially the case following the passing of the United States International Copyright or Chace Act of 1891, just as professional literary agents were coming into their own. In many ways, agents were especially critical for Australian authors seeking a wider market from a distance, and they emerge alongside in-house editors as among the most important gatekeepers and facilitators for those finding their way into the US market. Many of the case studies covered below indicate the importance of close working relations, professional but also often personal, between authors, agents and editors in enabling authors to establish their presence in the marketplace and the book talk that helped define it.

Within these structures, Australian novels made their way to American publishers along a wide variety of routes. Some authors, like Norman Lindsay and Patrick White, arrived in New York with books or manuscripts stowed in their luggage; some were noticed by American publishers or their agents in London; others built a reputation through the booming transatlantic magazine market; a few sent novels directly to American publishers in hope. Many others relied on their British publisher to cut a deal, whether simply out of commercial consideration or because of the publisher's faith in the book or its author, not an uncommon thing even where commercial prospects were uncertain. Increasingly, as suggested, authors relied on agents in London or New York to negotiate profitable deals in different territories. In many cases no direct evidence has survived as to why or how a particular book made its way to the United States despite the wealth of correspondence, contracts and production sheets in the archives, but we can often surmise through examination of the publisher's lists, its publicity, and the state of the market at the time of publication.

Australian authors could rarely escape the consequences of being located in or bearing the traces of belonging to a province within "international literary space". ${ }^{0}$ But at the same time they could be conscious of also belonging to an expanding global marketplace for fiction, not merely a restricted colonial market. A sense of distance or belatedness was almost always in tension with an awareness of the potential, at least, of inhabiting parallel or proximate worlds, a sense of contemporaneity with American as well as British or imperial book cultures. Ethel Turner's Seven Little Australians (1894) is a good example of this double equation, the book's title announcing its local address to the nation then coming into being but also explicitly referencing the two most influential children's books of recent decades, both from America: Louisa May Alcott's Little Women from 1868 and Frances Hodgson Burnett's Little Lord Fauntleroy from 1886. As we detail in Chapter 4, Turner aggressively sought US publication for several decades, changing publishers and literary agents and even writing an "American novel" in her quest for American success. More broadly, the rise of a self-consciously modern national literature in Australia as

10 Pascale Casanova, The World Republic of Letters, trans. M.B. DeBevoise (Cambridge, MA: Harvard University Press, 2005), xii, 1-15. 
manifested in the historical sagas and social realist fiction of the 1920 s to 1940 s was echoed in America's own search for a national story in the years culminating in Gone with the Wind (1936) and The Grapes of Wrath (1939). ${ }^{11}$

America, in short, was a significant part of the world a significant number of Australian authors imagined for their books - something acknowledged, for example, in the 1946 Australion Writers and Artists' Market, which printed advice from US literary agents about how to get published in America. ${ }^{12}$ Australia could in turn impress itself upon American publishers, readers and reviewers, and with something of the same tension between a sense of distance or difference and a sudden realisation of proximity or similarity. Although the present book does not aspire to be a history of American attitudes to Australia, it does pursue the critical reception of Australian works in the American marketplace. A major revelation from our study is just how widely Australian books were noted and discussed in the American press, if not necessarily as Australian books: in most cases more widely in the United States than in Australia, and in many cases more widely than in Britain too. Books were extensively reviewed, not only in the increasingly influential New York papers, but in city, regional and small-town newspapers across the nation, often accompanied by columns or paragraphs of gossip from the book world. The reviews were mostly original, but others could be syndicated across a dozen or more different papers. Alongside the newspaper book pages were the prestigious weekly and monthly magazines, older titles such as Harper's Magazine, Scribner's, the Bookman or Nation, and newer publications such as the New Republic (1914), American Mercury (1924), the Saturday Review of Literature (1924) and the New Yorker (1925). The newer magazines added more weight to New York's influence over the literary field.

This distinctive context of reviewing in newspapers, literary supplements and magazines, and in assessments in-house by editors and publishers' readers, cannot be generalised as representing the American understanding of Australia. It has its own temporality in the weekly or monthly cycles of reviewing, its own genres and institutional protocols, its own communities of interest. But within these productive limitations, the reception of Australian fiction in the United States shows something very like the dialectic between proximity and distance that Paul Giles emphasises in his re-reading of American writing through its antipodean consciousness. ${ }^{13}$ Australian books were often seen simply as British books, which - considered as tradeable property or commodities - the majority were. But the recognition of Australian distinctiveness or of unexpected parallels between Australia and the United States was also recurrent. In the late nineteenth century, Australian or Anglo-Australian novels might be considered as local variants of the broader themes of "Anglo-Saxon" fiction, a framing that could potentially bring them closer to American readers, closer even than their British contemporaries. A stronger sense of Australian difference (in relation to Britain) and of an unanticipated, even disconcerting sense of familiarity, might also be expressed - in the recognition of a distinctive form of "antipodean romance" in novels of the 1880 s and 1890 s for example, or, even more

11 Hutner, What America Read, Ch. 2, "The 1930s".

12 Australian Writers and Artists' Market (Including New Zealand): A Practical Selling Guide for the Freelance (Melbourne: Australian School of Journalism Pty Ltd and Art Training Institute Pty Ltd, 1946).

13 Paul Giles, Antipodean America: Australasia and the Constitution of US Literature (New York: Oxford University Press, 2013). 
forcefully, in the sudden acknowledgement of parallel histories in the pioneering or intergenerational sagas of the interwar years as represented by the marked success in America of Richardson's The Fortunes of Richard Mahony trilogy and Eleanor Dark's The Timeless Land.

But even when such recognition was at its strongest it co-existed with a sense of Australia's mere otherness, its banal rather than exotic remoteness, the sense that American readers were unlikely to be interested in an "ordinary" novel about Australia. Over successive decades, Australia and its literature were repeatedly discovered - as if for the first time - and then forgotten or ignored again until the next moment of surprise discovery. More than once, what appears to be a consolidation of knowledge about Australian books over a number of years suddenly dissolves, with little apparent "institutional memory" in American book culture of earlier Australian titles or authors.

The history we recount is thus as discontinuous as it is continuous; certainly, no evolutionary pattern of steadily increasing awareness of Australian authors or Australian literature emerges over the decades. Instead, we find periods of relatively high visibility in certain sectors of the market which are relatively quickly forgotten, high-profile individual careers which cannot be transferred in any substantial way to a literary reputation or an appreciation of Australian literature more generally, or sustained careers that owe everything to genre, say, and little or nothing to any national framing. One of the ways in which the present study challenges assumptions based on nationalist models is the sheer absence of that national framework accompanying Australian works as they make their way into the American marketplace. We discover familiar texts in unfamiliar contexts, stripped of the defining logic of their place in the developing national story. And we discover many more books and authors that have fallen out of that story but re-emerge in the foreground of the American marketplace or enter the American scene as very different kinds of books than they were taken to be in Australia or Britain. Norman Lindsay's reception as a modern novelist in New York is just one example.

The triangulation of Australia, Britain and the United States thus achieves exactly the kind of "elliptical refraction" that David Damrosch sees as characteristic of a world literature perspective or, better, a transnational perspective: "instead of seeing London as the center of a circle ... we can present the literary culture of London as one focus of an ellipse, or more precisely as one focus for many different, partially overlapping ellipses, each with a second focus elsewhere" (in our case London and Sydney, London and New York). ${ }^{14}$ To follow Australian works into the American market is indeed to discover an elliptical refraction of Australian literature as a national literature and of Australian books as Australian books. In a material sense, these "Australian" (or British) books become American books, often bearing traces of their cultural origins of course, but manufactured, distributed, sold and read as commodities within the domestic US marketplace. Only a small number of the Australian novels appearing in America were published or received as instances of Australian literature per se; only a handful of publishers, critics or reviewers were interested in the question, although again, at certain points, the degree to which the question does arise is surprising. Instead, Australian novels appeared in America among the new books of the season, as English fiction or "modern novels", as romances, detective

14 David Damrosch, "Literary Study in an Elliptical Age", in Comparative Literature in the Age of Multiculturalism, ed. Charles Bernheimer (Baltimore, MD: Johns Hopkins University Press, 1995), 129-30. 
tales or family sagas, as "light fiction" or serious literature. The national context was secondary - in publishers' decisions and reviewers' assessments - although certain books and authors could force it into view.

The absence of any sustained sense of Australian literature and the associated difficulty for Australian novelists of maintaining a reputation in American book culture between books or once new titles stopped appearing should not be surprising given Australia's peripheral status in the Anglophone literary world, the ease with which its books and authors "disappeared" into the larger sphere of British or English fiction, the relatively small number of Australian books appearing among the hundreds landing on reviewers' desks each week, and the lack of any established institutional support such as dedicated publishers' lists, college courses or critical studies. Indeed, for most of the period examined here, such institutional resources were underdeveloped in Australia itself despite the busy, crowded print culture that existed in its cities and towns. In Pascale Casanova's terms, Australia was poor in literary resources and literary capital, in literary institutions and prestige. ${ }^{15}$ What's surprising, indeed, is not the ignorance or apathy towards Australian literature that we can note periodically among American publishers and reviewers but the recurrent examples of critical or sales success, of publishers willing to invest in new titles by relatively unknown authors from a relatively unknown place, and of reviewers' interest in the Australian scene, however occasional these might be.

We have used the terms "Australian author" and "Australian book" without restrictive definition to this point, and we might claim to do so as a matter of principle not just convenience. The point is less about inclusiveness than adequacy to the wide range of historical trajectories - into and out of Australian time and space - that both books and authors have taken. One of the key insights of the transnational turn in book history and literary studies is an increased appreciation of the sheer mobility of books and authors across local and national boundaries. ${ }^{16}$ National literary space is an inadequate frame for containing or explaining the "careers" of either books or authors, especially in a study such as this which is explicitly located beyond those borders. Rather than a single national frame, we are working with a series of shifting frames - or "scales" in Robert Dixon's terms - and a diverse range of trajectories across local, national and international sites. ${ }^{17}$ As suggested below in Chapter 1, the "Australian" in this study is a shifting field or network that writers and writing entered or passed through in various capacities and for varying periods of time, leaving different kinds of historical traces. Its framing must be flexible enough to encompass immigration and emigration, expatriation - a major strategy for participating in international markets - imperial commuting, transpacific "adventurism", and many other forms of transnational mobility. The point applies as much to those who stayed at home - while their books moved across the globe - as to those who left to make careers elsewhere.

Nor do we dwell on the strict bibliographical definition of an "edition" (that is, a wholly new setting) or focus in detail on textual variations between editions, although we

15 Pascale Casanova, "Literature as a World", New Left Review 31 (January-February 2005): 83.

16 See, for example, Sydney Shep, "Books in Global Perspectives" and Alistair McCleery, "The Book in the Long Twentieth Century", in The Cambridge Companion to the History of the Book, ed. Leslie Howsam (Cambridge: Cambridge University Press, 2014), 53-67, 162-80.

17 Robert Dixon, "Australian Literature, Scale, and the Problem of the World", in Text, Translation, Transnationalism: World Literature in 21 st Century Australia; ed. Peter Morgan (North Melbourne, Vic.: Australian Scholarly Publishing, 2016), 173-95. 
discuss revealing instances of changes made to texts and titles for American publication. More importantly, we register throughout the differences in how books appeared in the American marketplace, whether as new copyrighted American editions, new editions printed from English sheets, reprints from earlier American, British or Australian editions, or in other forms of reissue and distribution, for these have a significant bearing on the position of a book in that marketplace. We can talk about an Australian novel and an American book and mean the same thing, because of strict national regulations such as the Chace Act's "manufacturing clause", which demanded that literary property be printed and bound within the United States in order to be eligible for copyright protection. ${ }^{18}$ For the vast majority of cases in this study, the Australian novel under discussion is an American book because it was made (if not born) in the USA.

As these arguments all indicate, the present study is framed necessarily as a contribution to transnational literary or print culture studies. It breaks down the model of an organically evolving entity - "Australian literature" - gradually filling the space of the nation, as it were, until it is adequate to itself, at once modern and mature as criticism has so often demanded. ${ }^{19}$ Instead, as we put it below, we discover a literature that was international (and not merely imperial) long before it was national, and long after as well. From this enlarged perspective, instead of a parochial, backward period across the first two or three decades of the twentieth century, for example, we find Australian authors published widely alongside their international contemporaries in the two main Anglophone book markets. Instead of a local, provincial tradition of historical sagas we find Australian novels taking their place in the 1930s and 1940s alongside American and other international examples of the genre. None of this is to ignore the relatively weak, marginalised position of Australian books and authors in the world of letters or the legal, economic and other obstacles that so often defeated Australian writers' aspirations to a wider market. Nor is it to dismiss the serious, principled commitments of nationalist intellectuals and writers seeking to build a national literature in Australia. But it does suggest the significance of the United States to the long transnational history of Australian literature.

In addition to its larger conceptual moves beyond the logics of national cultural evolution, transnationalism in literary studies has been productively identified as an energising or confounding force in literary texts themselves, an imaginative capacity (and capaciousness), often manifest in complex forms of citation and multiple perspectives. ${ }^{20}$ As a textual quality - or reading practice - transnationalism often comes to have an ethical as well as an intellectual force. At this point, however, more materialist approaches might

18 See Paul Eggert, Securing the Past: Conservation in Art, Architecture, and Literature (Cambridge: Cambridge University Press, 2009), 214-40, where he outlines the notion of the literary work as a regulating concept that allows us to talk about each edition under the same name (e.g. Robbery Under Arms or Coonardoo), but, at the same time, to separate one material book from another by acknowledging the mechanical, temporal and spatial properties that each book exhibits.

19 Carter, Always Almost Modern, 15-33.

20 See, for example, Dixon, "Australian Literature, Scale, and the Problem of the World"; "Scenes of Reading: Is Australian Literature a World Literature?", in Republics of Letters: Literary Communities in Australia, ed. Robert Dixon and Peter Kirkpatrick (Sydney: Sydney University Press, 2012), 71-83. Also Paul Giles, Transatlantic Insurrections: British Culture and the Formation of American Literature, 1730-1860 (Philadelphia: University of Pennsylvania Press, 2001); Transnationalism in Practice: Essays on American Studies, Literature and Religion (Edinburgh: Edinburgh University Press, 2010). 
sound a cautionary note, for as an ethical or aesthetic category the transnational all too easily becomes a mode of transcendence, its metaphors of border-crossing merely the latest in a long line of such euphemisms for literariness or liberation. From the perspective of publishing or book history, by contrast, certainly in the history examined here, we are confronted at every turn by the unequal distribution of power in the literary world system, the material and legal obstacles to border-crossing, and the insistent presence of national legislative or domestic market regimes, protecting local production and administering cultural flows. Transnationalism in this perspective is less a higher form of literary being than a mundane, if often conflicted cluster of institutional arrangements, formal agreements and habitual practices involving publishers, agents, copyright laws, distribution networks and so on, and operating variously on local, national and international scales. As Paul Eggert reminds us, "only some works 'travel", and decisions are made "that permit the process to occur. Those decisions are made mainly by the book trade: the transnationalising phenomenon has a material basis" 21

In some ways the present history might be described as "transnodal" rather than transnational given the dominance of London, New York and Sydney/Melbourne over their respective domestic markets, markets which were segmented and diversified internally and thus never identical with the nation. At the same time the continued significance of the national plane might be indicated by the centrality of copyright, an eminently international set of arrangements across most of the period examined here but one organised precisely through the recognition of distinct national territories. We can certainly speak of an international market for books, but one which is configured differently in each national and local situation. Domestic, national and international forces operate through each of the nodes relevant to the history of Australian books and authors in the American marketplace.

Chapter 1 examines the presence of Australian fiction and earlier travellers' tales in the United States in the second half of the nineteenth century. By the late 1880s and $1890 \mathrm{~s}$, Australian novels became identifiable as a distinct variation upon familiar, transatlantic romance conventions. Their visibility in the American marketplace depended in part on the booming fiction reprint industry and fiction libraries, largely driven by "pirate" publishers before the passing of the US International Copyright Act in 1891.22 Chapter 2 focuses on the American and transatlantic careers of Rosa Praed and Louis Becke, both of whom received extensive critical praise in America over successive titles but who struggled to maintain their careers, due in different parts to the nature of their own output, the complexities of the copyright situation, and the changing values accorded to romance and realism in the literary field. Chapter 3 follows a group of writers whose careers overlap with those of Praed and Becke either side of the century's turn, but which depend rather on the emergence of the "new" genres of detective fiction, mysteries, spy stories and thrillers. The genre system itself multiplied the potential mobility of fiction across national borders and limited markets, and Australian authors were significant players in the new game.

Chapter 4 turns to the first three decades of the twentieth century, beginning with the relative decline in numbers of Australian novels published in the United States as a

21 Paul Eggert, Biography of a Book: Henry Lawson's "While the Billy Boils" (Sydney: Sydney University Press, 2013), 22.

22 As is explained in Chapter 1, "pirate" is a disputed term as the reprinters were not acting illegally in the absence of international copyright legislation protecting foreign editions. 
zonsequence, in part, of the restrictive clauses of the new US international copyright law. Even so, the number of works published - many one-off titles but also successive books rom authors with sustained careers - provides a much richer sense of Australian writing in hese years. Australian works were able to participate in a range of different market sectors - "geographical romances", women's travel writing, the "modern girl" story, and, not least, the modern sex novel. Chapter 5 returns to the question of genre fiction, here from the 1920s to the 1940s (and beyond for the most successful authors). Again Australian authors emerge as major players in the game, most notably Arthur Upfield in crime and Maysie Greig in romance, managing transatlantic and, in their case, transpacific careers - although it was another romance author, Alice Grant Rosman, who was promoted as "America's best loved novelist".

Chapters 6 and 7 cover the period in the present study in which Australian literature had its greatest impact as "literature", and as "Australian" literature, from the late 1920s to the mid-1940s. Over these years a series of important novels appeared in America, and were received into a culture receptive to their generic ambitions as pioneering epics, family sagas and regional novels. Critics and reviewers commented repeatedly - with surprise - on the achievement of these novels and the parallels they saw with Americass own story. Henry Handel Richardson's Ultima Thule, published by Norton in 1929, had extraordinary success critically and commercially; Norton followed with Richardson's other titles and two works by Katharine Susannah Prichard, enabling reviewers to begin connecting different Australian works, from M. Barnard Eldershaw's A House is Built to Frank Dalby Davison's Red Heifer to Xavier Herbert's Capricornia. ${ }^{23}$ Dark's The Timeless Land, like Ultima Thule an American Book-of-the-Month Club selection, frames the period.

The careers of the two authors many would regard as the most important Australian novelists of the twentieth century - Christina Stead and Patrick White - are centrally stories of New York publishing and book reviewing. Their careers through to the early 1950 s are the focus of Chapter 8. America was a publishing home for both but also a complex sign of their literary "homelessness" and their relation to an emerging modern tradition of the novel in these formative years. Chapter 9 gathers together many of the threads from previous chapters and brings them to bear on the final years of the period under study, the 1940s and especially the postwar years, when many believed or hoped that the presence of Australian literature in America could be consolidated or at least that a new period of growth was likely. While the Pacific war did prompt increased interest in Australian books, this interest appears to have been very short-lived and had little impact on publishers' attitudes or decisions. While certain writers, such as Kylie Tennant, found modest success in America, there was little continuity from the achievements of the interwar years. For new writers such as Jon Cleary it was a matter of starting from scratch and negotiating again the (often two-sided) triangle of American, British and Australian publishing markets.

23 Red Heifer: A Story of Men and Cattle was the US title of Davison's Man-Shy. 


\section{SYDNEY STUDIES IN AUSTRALIAN LITERATURE}

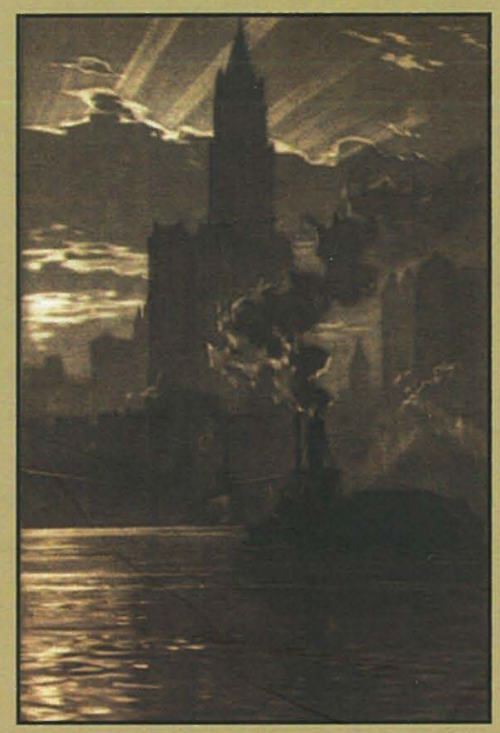

Australian Books and Authors in the American Marketplace 1840s-1940s explores how Australian writers and their works were present in the United States before the midtwentieth century to a much greater degree than previously acknowledged. Drawing on fresh archival research and combining the approaches of literary criticism, print culture studies and book history, David Carter and Roger Osborne demonstrate that Australian writing was transnational long before the contemporary period. In mapping Australian literature's connections to British and US markets, their research challenges established understandings about national, imperial and world literatures.

Carter and Osborne examine how Australian authors, editors and publishers engaged productively with their American counterparts, and how American readers and reviewers responded to Australian works. They consider the role played by British publishers and agents in taking Australian writing to America, and how the international circulation of new literary genres created new opportunities for novelists to move between markets.

Some of these writers, such as Christina Stead and Patrick White, remain household names; others who once enjoyed international fame, such as Dale Collins and Alice Grant Rosman, have been largely forgotten. The story of their books in America reveals how culture, commerce and copyright law interacted to create both opportunities and obstacles for Australian writers.

David Carter is Professor of Australian Literature and Cultural History in the School of Communication and Arts at the University of Queensland.

Roger Osborne is Lecturer in English and Writing at James Cook University, Cairns.

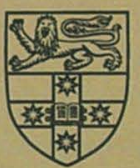

SYDNEY UNIVERSITY PRESS sydney.edu.au/sup

ISBN: 978-1-74332-579-7

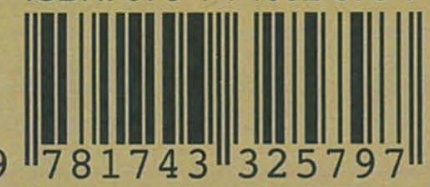

